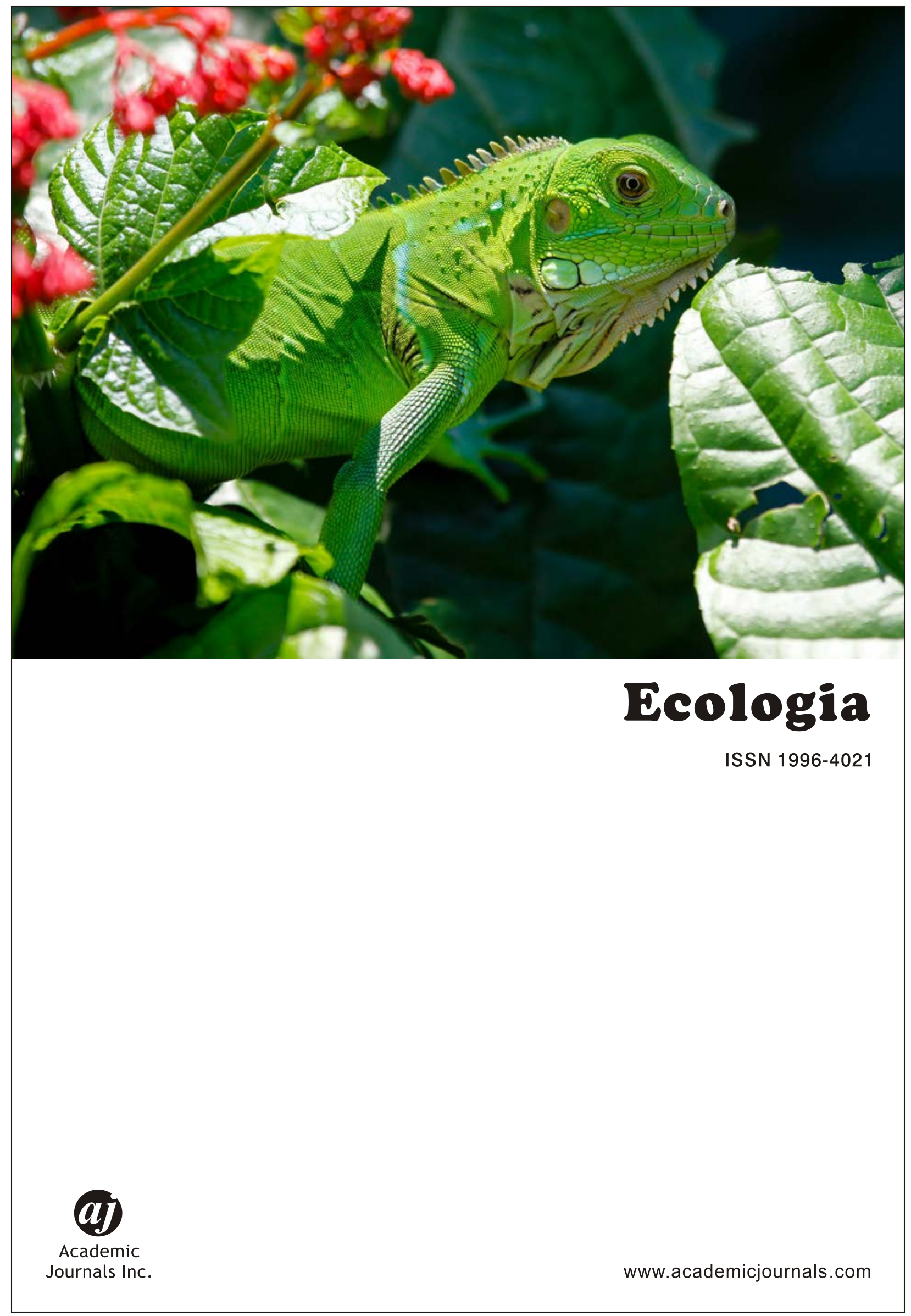


DOI: $10.3923 /$ ecologia.2019.1.9

\title{
Review
}

\section{Environmental Implications, Properties and Attributes of Crude Oil in the Oil-producing States of Nigeria}

\author{
${ }^{1}$ Edokpolor Osazee Ohanmu, ${ }^{2}$ Sunday Paul Bako, ${ }^{3}$ Erhunmwunse Ohanmu and \\ ${ }^{4}$ Osayuwame Osaretin Ohanmu
}

${ }^{1}$ Department of Biological Sciences, Faculty of Science, Edo University, lyamho, Edo State, Nigeria
2Department of Botany, Faculty of Science, Ahmadu Bello University, Zaria, Nigeria
${ }^{3}$ Department of Health, Safety and Environment, Faculty of Education, University of Benin, Nigeria
${ }^{4}$ Department of Chemistry, Faculty of Science, Federal University of Petroleum Resource, Effurun, Nigeria

\section{Abstract}

In Nigeria, oil exploitation occurs in the Niger Delta region which is one of the world's largest wetlands and includes by far the largest mangrove forest in Africa with a biological diversity of global significance. The study aimed in creating a synergy between the environment, farming system and crude oil sector with the need of government to implement feasible policies that will protect the health of all for a sustainable ecosystem. This review was achieved by using the online archives and personal interactions. The high demand for and use of petroleum and its derivatives worldwide has made petroleum hydrocarbon contamination a global problem with serious health and environmental consequences. One of the environmental challenges posed by oil pollution is the alteration in the physical and chemical nature of the soil which subsequently affects the growth of plants. Petroleum hydrocarbon contamination may affect plants by retarding seed germination and reducing height, stem girth, photosynthetic rate or resulting in complete mortality. In this review, relevance of crude oil in Nigeria and its environmental implication to the ecosystem was highlight.

Key words: Crude oil, Niger Delta, sustainable ecosystem, oil pollution, petroleum hydrocarbon contamination

Citation: Edokpolor Osazee Ohanmu, Sunday Paul Bako, Erhunmwunse Ohanmu and Osayuwame Osaretin Ohanmu, 2019. Environmental implications, properties and attributes of crude oil in the oil-producing states of Nigeria. Ecologia, 9: 1-9.

Corresponding Author: Edokpolor Osazee Ohanmu, Department of Plant Biology and Biotechnology, Faculty of Science, Edo University, lyamho, Edo State, Nigeria Tel: +2347084059346

Copyright: ( 2019 Edokpolor Osazee Ohanmu et al. This is an open access article distributed under the terms of the creative commons attribution License, which permits unrestricted use, distribution and reproduction in any medium, provided the original author and source are credited.

Competing Interest: The authors have declared that no competing interest exists.

Data Availability: All relevant data are within the paper and its supporting information files. 


\section{INTRODUCTION}

The natural functioning of the environment provides both goods and services such as food and other products on which man depends upon for the continuity of life'. The ecosystem stores large amount of carbon in both plants and soils and this regulates water flow and water quality and also assist in the stabilization of local climates ${ }^{2}$. These services are not meant for financial value, but man nonetheless depends on them for survival'.

Niger Delta environment is one of the world's largest wetlands and includes by far the largest mangrove forest in Africa ${ }^{3}$. It can be broken down into four ecological zones: coastal barrier islands, mangrove swamp forests, freshwater swamps and lowland rainforests ${ }^{4}$. In addition to support abundant flora and fauna, it contains arable terrain that can sustain a wide variety of crops, lumber or agricultural trees and more species of freshwater fish than any ecosystem in West Africa ${ }^{5}$.

This incredibly well-endowed ecosystem contains one of the highest concentrations of biodiversity on the planet ${ }^{1}$. Its biological diversity is of global significance. The Niger Delta covers $20,000 \mathrm{~km}^{2}$ within wetlands of $70,000 \mathrm{~km}^{2}$ formed primarily by sediment deposition ${ }^{3}$. This floodplain is the home to 20 million people and 40 different ethnic groups and makes up $7.5 \%$ of Nigeria's total land mass ${ }^{6}$. It is the largest wetland and maintains the third-largest drainage basin in Africa ${ }^{6}$. Within this extremely valuable ecosystem, oil exploration and exploitation activities are widespread. The advent of oil as the world's leading fuel was partly due to its relative cleanliness but the enormous scale of the petroleum industry's operation has inevitably created a new set of difficult environmental problems as being experienced today in the Niger Delta region of Nigeria ${ }^{7-9}$. Among these environmental problems, crude oil pollution is becoming serious day by day. One of the biggest concerns associated with crude oil pollution in the environment is the risk to farmlands ${ }^{3}$ and fisheries and contamination of potable drinking water ${ }^{5}$, since most of the people's livelihood depends on farming, fishing and usage of water for their domestic purpose ${ }^{10}$.

Transportation of crude oil or its products from the point of production to that of processing has resulted in its spillage with adverse consequences. Oil blowouts have also occurred during extraction stage and when these happen, the oil empties itself either in the soil or water bodies while the volatile components escape to the atmosphere'. When crude oil spills on land, it affects the soil in diverse ways. It is known that some crude oil components can directly affect soil organisms and other soil properties ${ }^{10}$.
Over the years, the utilization of crude oil and its refined products has been on the increase globally. As a result, concerted efforts are being made to understand its composition, structure and properties. This review attempted to bridge the dearth knowledge on the impact of the Nigeria crude oil production to the livelihood and environment as a whole, thereby elaborating on some of its components, the effects it has on the agricultural and health system of the country with a burgeoning population of about 170 million estimated to double by 2050. The objective of this review was to create a synergy between the environment, farming system and crude oil with the need of feasible policies implementation by government that will protect the health of all for a sustainable ecosystem.

\section{PETROLEUM}

Petroleum is defined as a substance generally liquid, occurring naturally in the earth and composed mainly of mixtures of chemical compounds of carbon and hydrogen with or without non-metallic elements such as sulphur, oxygen and nitrogen. The word petroleum comes from the Latin word, 'rock oil'11. Petroleum according to World Resource Institute $(\mathrm{WRI})^{12}$ is referred to a mixture of naturally occurring hydrocarbons found beneath the earth's crust. This petroleum compounds occurs in various forms. They are called natural gas when occurring in the gaseous forms, crude oil when occurring in the liquid form and asphalt or tar associated with oil, sand and shale when occurring in the solid or semi-solid form $\mathrm{Odu}^{13}$. Petroleum products are made up of a number of complexities such as gaseous methane ranging from a molecular weight of $16-20,000 \mathrm{~g}$ mole $\mathrm{e}^{-1}$. According to Clark and Brown ${ }^{14}$, hydrocarbons are classified into three broad groups each with sub classes. They are:

- Aliphatic hydrocarbons

- Alicyclic hydrocarbons

- Aromatic hydrocarbons

Aliphatic hydrocarbons: They are also referred to as open chain compound and are categorized into two. If there is only a single bond between all adjacent carbon atoms, the molecules is said to be saturated. If the carbon atom has at least one double or triple bond, it is said to be unsaturated. Examples of saturated aliphatics are paraffins or alkenes and are chemically more stable than the unsaturated aliphatics. Naturally, the unsaturated aliphatics do not occur in crude oil but are produced during industrial photochemical refining or by processes after crude oil spill ${ }^{14}$. 
Alicyclic hydrocarbons: These hydrocarbons are both saturated and unsaturated and have some or their entire carbon atom arranged in a ring structure ${ }^{14}$.

Aromatic hydrocarbons: These are hydrocarbon that contain at least six-carbon ring in their molecular structure. They have the following basic formula $\mathrm{CxHx}$ ring. Benzene is one of the many aromatic compounds present in petroleum and crude oil contributing to the octane rating of petrol. It is therefore; of economic importance to petrol-driven engines. Benzene is a clear, colorless and inflammable liquid'.

\section{CRUDE OIL}

Crude oil is formed over millions of years deep under the ground from the remnants of forests and from a mixture of comparatively volatile liquid hydrocarbons (compounds composed mainly of hydrogen and carbon with some nitrogen, sulphur and oxygen) that occurs in the earth's crust $^{11}$. While it is a naturally occurring substance, it can be highly toxic and it burns fiercely ${ }^{15}$. Some of its products include: fuel oil, sludge and refined products such as petrol, diesel and kerosene'.

Crude oil, described as the world's treasure ${ }^{15}$, is a vital resource which sustains and promotes economic growth of many nations, including Nigeria. Oil is used as fuel to run various types of engines of cars, planes, ships, tractors and trucks and is also used to generate a large portion of the world's electrical-power supply. It is customary used to identify two closely related compounds-natural gas (also known as methane) and oil. Both substances sometimes seep to the surface through cracks in the earth. Crude oil can be liquid or in form of asphalt, pitch, bitumen or tar ${ }^{8}$.

In Nigeria, oil has been reported by Adegeye et al. ${ }^{16}$ as the 'Life wire' of the Nigeria economy and is produced mainly in the Niger Delta region. Oil producing states in the region include: Awka-Ibom, Bayelsa, Delta, Edo, Imo, Ondo and Rivers States. The oil produced account for $90 \%$ of Nigeria's national income ${ }^{1}$. Nigeria became an exporter of oil when production reached 6000 barrels per day ${ }^{17}$.

\section{PHYSICAL PROPERTIES OF CRUDE OIL}

Crude oil contains a wide range of hydrocarbon-based substances. Hydrocarbons are compounds composed of the elements; hydrogen and carbon. This included substances that are commonly thought of as oils, such as crude oil and refined petroleum products with each type of oil having a distinct physical properties ${ }^{1}$. These properties affected the way oil will spread and break down, the hazard it may pose to aquatic and human life and the likelihood that it will pose a threat to natural and man-made resources. The rate at which an oil spill spreads will determine its effect on the environment. Factors which affected the ability of an oil spill to spread include surface tension, specific gravity and viscosity ${ }^{18}$.

Surface tension: This is the measure of the attractive force between the surface molecules of a liquid. The force functions to keep the molecules or restrain them from escaping into the air. The higher the oil's surface tension, the more likely a spill will remain in place. If the surface tension of the oil is low, the oil will spread even without help from wind and water currents. Because increased temperatures can reduce a liquid's surface tension, oil is more likely to spread faster in warmer waters than in very cold waters.

Specific gravity: This is the density of a substance compared to the density of water. Since most oils are lighter than water, they float on top of it. However, the specific gravity of an oil spill can increase if the lighter substances within the oil evaporate. Heavier oils, vegetable oils and animal fats may sink and form tar balls or may interact with rocks or sediments on the bottom of the water body.

Viscosity: This is the measure of a liquid's resistance to flow. The higher the viscosity of the oil, the greater the tendency for the oil to stay in one place ${ }^{18}$.

\section{CHEMICAL COMPOSITION OF CRUDE OIL}

Crude oils vary widely in chemical composition depending on their sources. Crude oil from the same source may show variation in chemical composition as extraction progresses ${ }^{1}$. Hydrocarbon is one of the major components of crude oil constituting mainly of hydrogen and carbons in various molecular arrangements. These include straight chain, branched and cyclic alkanes, aromatics and traces of alkanes. Other organic and inorganic component of crude oil includes sulphur, nitrogen and oxygen. Sulphur containing compounds including naphthenic acids, carboxylic acids, ketones, esters, xylols ${ }^{19}$ and phenols while nitrogen containing compounds including cycloalkyl thiols, alkyl thiols and sulphur-aromatics are all present. Crude oil also contains heavy metals such as iron, nickel, cobalt, copper, vanadium and nickel'. They are collectively called heteroatoms. Udo and Fayemi ${ }^{19}$ reported that hydrocarbons have more carbon than nitrogen, 
increasing the C:N ratio and noted that extractable phosphorus decreases with hydrocarbon addition. Micronutrients like magnesium and calcium increase with hydrocarbon addition ${ }^{20}$.

Crude oils contain lighter fractions similar to gasoline, heavier tar or wax constituents and vary in constituents from a light volatile fluid to a semisolid. Odebunmi et al.21 , however noted that, heavier crude oil produces higher fractions of kerosene, gas oil and other higher-boiling fractions. The Nigeria light crude oil contains higher percentage of naphthenic hydrocarbon and the Nigeria medium crude has a higher specific gravity and more of the boiling point residue ${ }^{13}$ with above $370^{\circ} \mathrm{C}$.

\section{USES OF CRUDE OIL}

Life without petroleum and it products would have been difficult now that the world is yet to discover an alternative fuel lubricant. Lubricating oil lessens frictions, thus slowing the breakdown of machine components. Oil is used as fuel for planes, automobiles and heating systems. A lot of cosmetics, paints, inks, drugs, fertilizers and plastics as well as myriad of other items contain petroleum products.

\section{POLLUTION}

FEPA $^{22}$ defined pollution as man-made or man-aided alteration of chemical, physical or biological quality of the environment to the extent of been detrimental to that environment or beyond acceptable limits. Pepper et al.23, defined it as the addition of persistent toxic compounds, chemicals, salts, radioactive materials or disease causing agents which have adverse effects on plant growth and animal health. Similarly, it won't be out of place to define pollution generally as the change in the physical, chemical or biological characteristics of the air, land and water that can harmfully affect human life and desired plant species, industrial processes, living conditions and cultural assets.

Agbogidi ${ }^{24}$ in a study observed that crude oil pollution is an inevitable consequence of oil exploration and exploitation activities both in oil producing and consuming areas due mainly to accidental discharge, human error, sabotage, transportation, natural causes, etc. Thus, it creates a negative effect on vegetation, both directly and indirectly. Nwilo ${ }^{25}$ presented data to show that $50 \%$ of oil spills in Niger Delta is due to pipeline corrosion, $28 \%$ sabotage, $22 \%$ to oil production operations and engineering drills.

Oil pollution in the Niger Delta has been a major source of concern to the people living in the crude oil-rich-areas ${ }^{26}$. Oil spills adversely affect the nutrient level and fertility status of the soils, thereby affecting the growth of agricultural crops ${ }^{2}$. In Nigeria, a substantial amount of crude oil is spilled annually. For example, Nwankwo ${ }^{27}$ reported 2,000 oil spillages in Nigeria between 1976 and 1988. During this period about $2 \times 10^{6}$ barrels of crude oil were spilled into the environment. Al-Qahtani ${ }^{28}$ stated that the crude oil contains a number of organic compounds removed as solid wastes from the oil refinery which can cause significant environmental instabilities.

On January 21, 2010, about 1,245 barrels of crude oil was spilled in Edo state following malfunctioning of the Nigerian National Petroleum Company equipment ${ }^{18}$. The spill allegedly destroyed about 169,231 farmlands. Spillage of crude oil on soil makes it unsatisfactory for plant growth as a result of insufficient aeration of the soil as air is displaced from the spaces between the soil particles by crude oil5. This affects the soil and its productivity in terms of the growth of crops. One of the environmental challenges posed by oil pollution is the alteration of the physical and chemical nature of the soils which subsequently affects the growth of plants ${ }^{29}$. This alteration is achieved by many means including the reduction of the $\mathrm{pH}$ content of the soil. This affects the soil and its productivity in terms of the growth of plants.

Consequences of oil pollution: Due to the ineffectiveness of purification systems, wastewaters may become seriously dangerous; leading to the accumulation of toxic products in the receiving water bodies with potentially serious consequences on the ecosystem ${ }^{17}$. The environmental consequences of crude oil pollution on the inhabitants of Ologbo in Edo state are enormous. Crude oil pollution has degraded most agricultural lands in the area and has turned hitherto productive areas into wastelands. The increased soil infertility due to the destruction of soil micro-organisms and dwindling agricultural productivity, farmers have been forced to abandon their land to seek alternative means of livelihood which may be non-existent ${ }^{30}$.

Soil acidity or alkalinity otherwise known as soil pH is a most crucial factor in determining the performance of soils with respect to plant growth'. Besides controlling the degree of nutrient availability to plants, it also controls microbial environment necessary for optimum crop growth ${ }^{31}$. Considering this large quantity of crude oil going into the environment, especially farmlands and the fact that the inhabitants of these areas are subsistence farmers, there is an urgent need for the various agencies connected with oil production in Nigeria to pay more attention to the problem of oil spillage. 
Sources of oil pollution: The known sources of environmental pollution from petroleum industrial operations worldwide include the following: transportation of petroleum products, operational discharge, oil well blow-outs, leakage of oil storage tanks and pipelines, refinery effluents discharged into the environment, natural oil seeps, industrial municipal wastes, urban and rural run off, biosynthesis, atmospheric fall out, dry docking, terminal loading and other accidental discharge of waste oil ${ }^{1,25-28}$.

\section{ENVIRONMENTAL IMPLICATION}

Oil pollution on most agricultural lands have turned hitherto productive areas into wastelands with the alteration of physicochemical properties of the soil and dwindling agricultural productivity has led to redundancy in farming and fishing activities resulting in urban and rural migration, in oil producing area due to the attendant economic downturn ${ }^{30,31}$.

Developing countries are faced with critical environmental problems arising from poor to non-existent environmental management plan. Some of these problems are caused by:

- Improper disposal of household refuse

- Open-air disposal of sewage waste forming sewage lagoon

- Flooding brought about by poorly designed drainage

- Desertification occasioned by massive deforestation leading to the destruction of water catchments areas and hence less rainfall

- Oil spillage in petroleum producing communities: This produces a twin problem of polluting the land, rivers and creeks, thus exterminating a considerable percentage of the aquatic faunal population

- Discharge of untreated industrial effluent including gases

Effect of oil pollution on soil: Environmental degradation of the oil-rich Niger Delta region has been wanton and continuous with dire health, social and economic consequences for the people ${ }^{1,25}$. The emergence of oil as the world's leading fuel was partly due to its relative cleanliness but the enormous scale of the petroleum industry's operation has inevitably created a new set of difficult environmental problems as being experienced today in the Niger Delta region of Nigeria ${ }^{7-9}$. When crude oil spills on soil, its condition could become unsatisfactory for plant growth because of insufficient aeration as the air-filled pore space are reduced due to the hydrophobic layer of such soils ${ }^{9}$ and increased demand for oxygen as a result of oil decomposing organisms $s^{8,31}$. Crude oil pollution leads to the unavailability of mineral nutrients in soils and have been reported to cause such harmful effects as leaf chlorosis, necrosis, growth stunting in shoots and roots thereby leading to a reduction in biomass accumulation ${ }^{32,33}$.

Abii and Nwosu² reported a significant decrease in the $\mathrm{Ca}, \mathrm{K}, \mathrm{P}$, as well as a significant increase in the sand fraction and content of oil spill affected soils. Similar studies carried out by Khamehchiyan et al..$^{34}$ using sandy loam soil polluted with crude oil also confirmed pronounced changes on the physicochemical and the microstructure of the oil contaminated soil. Oil contamination of soil also limits normal diffusion processes thereby reducing the availability of nutrients in the soil to the plants ${ }^{35}$. Russe ${ }^{36}$ reported that soil saturated with natural gas could cause severe physical and chemical changes. These changes could result in the unavailability of nutrients to plants cultivated in soils polluted with crude oil causing many harmful effects.

Effect of oil pollution on plants: Many authors have demonstrated the phytotoxic effects of crude oil on crop, plants and tree species ${ }^{24,37-41}$. These effects have been observed to occur due to interference with plants' uptake of nutrients and the unfavorable soil conditions created due to crude oil pollution. Chindah and Braide ${ }^{42}$ in a study on the effect of oil spill on crop production in the Niger Delta reported that oil spill on crops caused great damage to the plant community due to high retention time of oil occasioned by limited flow. The oil hampered proper soil aeration as oil film on the soil surface acts as a physical barrier between air and the soil. Thus, it affects the physicochemical properties of the soil such as temperature, soil structure, nutrient status and $\mathrm{pH}$.

Gaseous pollutants such as sulphur dioxide and nitrous oxides enter the plant leaves through the stomata and affect the palisade and mesophyll cells causing leaf collapse, damage to the plastids and hence irreversible loss of photosynthetic capacity ${ }^{43}$. It has been reported in this review that crude oil could penetrate into plants by moving within the intracellular spaces and possibly in the vascular system. Plants and soil microbes compete for the little nutrient available in soils polluted with crude oil thereby suppressing the growth of plants in such soils. Omosun et al.44 reported that plants are highly susceptible to oil exposure and this may kill them within a few weeks to several months. According to Amakir and Onofegera ${ }^{45}$, the effect of crude oil pollution depends on the type and amount of oil involved, soil type, 
time of the year, the species and age of plants concerned. $\mathrm{Odu}^{13}$ reported that pollution effect on plants system are a function of exposure time of the pollutant, the manner of disposal and the innate genetic response of the plant system as modified by environmental influences. Plants grown in oil polluted environment are generally retarded with chlorosis of leaves coupled with dehydration of the plant ${ }^{46}$.

Effects of crude oil on crop plants: Ebenezer et al. ${ }^{47}$ showed the negative impact of oil spill on agricultural production. Some of these negative impacts include reduction in crop yield, pollution of rivers for fishing, land productivity and reduced farm income and standard of living of the people. Many researchers have studied the effects of crude oil on seed germination of crop plants ${ }^{23,45,46}$. Achuba ${ }^{48}$ studied the effect of crude oil contaminated soil at various sub lethal concentrations on the growth and metabolism of cowpea (Vigna unguiculata) seedlings showing that crude oil induced environmental stress in the seedlings, thereby hindering the productivity of the plant. Similar effect was also observed in soil contaminated with Bonny light whole crude or its fractions on the germination of beans (Phaseolus vulgaris $L$.) and maize (Zea mays L.) ${ }^{49}$. They reported that, dose dependent reduction in the number of bean or maize seeds that germinated in the contaminated soils compared with the control.

Ekpo and Nwankpa ${ }^{50}$ contributed that, while soil polluted with $1 \%$ crude oil enhanced the sprouting of ginger (Zingiber officinale), 15\% crude oil pollution completely suppressed the sprouting of ginger. Ekpo and Ebeagwu ${ }^{33}$ also reported the increasing concern regarding guard against crude oil pollution of arable agricultural land in order to maintain the quest for sustainable agricultural productivity. In polluted soil, Asoque et al. ${ }^{11}$ reported that okra (Abelmoschus esculentus) and fluted pumpkin (Telfairia occidentalis) seeds showed a delayed germination in the 2 and $4 \%$ crude oil treated soils and a total inhibition of germination in the $8 \%$ crude oil treated soils. Lack of seed germination in crude oil has been severally associated with oil induced loss of vitality or with unfavorable soil condition ${ }^{46}$.

However, the study of the accessions of Glycine max and Lycopersicon esculentum for germination, survival and growth by Njoku et al.52, also revealed that the different accessions of these crops have different levels of tolerance to crude oil polluted soil. Merckl et $a / . .^{53}$ reported the death of C. mucunoides, C. brasilianum and S. capitata six weeks after germination in the crude oil contaminated soil. According to Merckl et al.53, the reason for the death of the plants after germination could be as a result of continual exposure of the crops to crude oil in the soil. Also, Merckl et al.53 reported that oil prevents perforation of water into the soil leading to limited moistening effect in the root area. This could also lead to death of the crops after germination as the germinated seedlings could have died as a result of the uptake of phytotoxic compounds present in the crude oil ${ }^{54}$.

Effect of crude oil on photosynthesis: Photosynthesis in plants can also be affected directly through the alteration of cell membrane as a result of constant uptake of heavy metals into their system 1 . The crude oil in soil creates an unsatisfactory condition for plant metabolism due to insufficient aeration brought about by an increase in oxygen demand by oil decomposing micro-organisms ${ }^{46}$. Smit et al/.38 also reported stomata closure and decrease in leaf, stem and root dry weight in poorly aerated soils. This can be attributed to the decrease in plant dry weight and plant fresh weight as the crude oil concentrations increased. The yield of a crop is a complex trait affected by genetically controlled physiological components ${ }^{55}$. Crude oil contamination of soil has been reported to cause reduction in the germination, growth performance and even yield of plants $46,56,57,39$.

Studies have showed that oiled shoots of crops like pepper and tomatoes may wilt and die off due to blockage of stomata thereby inhibiting photosynthesis, transpiration and respiration ${ }^{46}$. In fact, the germination, growth performance and yield of these crops were stifled by oil spillage ${ }^{37}$. Dung et al. ${ }^{58}$ explored the spatial variability effects of gas flaring on the growth and development of cassava, water leaf and pepper, which are crops commonly cultivated in the Niger Delta. Results showed retardation in crop development manifested in decreased dimensions of leaf lengths and width of cassava and pepper crops closer to the gas flare point.

Effects of heavy metals on plants: Madejon et al..$^{59}$ defined heavy metals as a member of a loosely defined subset of elements with densities of $5.0 \mathrm{~g} \mathrm{~m}^{-3}$ or greater. Some heavy metals are essential as micronutrients for plant growth and development. For instance, copper plays an important role in several plant metabolic processes. It activates enzymes by incorporating it into metalloenzymes of the electron transport system and is involved in protein synthesis, carbohydrate, nucleic acid and lipid metabolism'1. It forms complexes with DNA and RNA and affects the stability of these components. Vanadium was also found to stimulate growth in Lettuce and Asparagus at unusually high concentration of 27 ppm in Kuwait crude oil ${ }^{60}$. 
However, at excess amount, heavy metals have a pronounced effect on plants growth ${ }^{46}$. Heavy metal accumulation in plants may lead to poor growth resulting in yield reduction. Lead and cadmium have been reported by Epstein ${ }^{61}$ to prevent mineral uptake by either synergistic or antagonistic reactions. Khan and Frankland ${ }^{62}$ studied the effect of cadmium and lead on the growth of radish, which resulted in the death of the plant within 3 weeks of contact when contaminated with $1000 \mu \mathrm{Cd} \mathrm{g}^{-1}$.

\section{CONCLUSION}

This review concluded that crude oil is a major source of energy that drives industrialization in the world especially Nigeria. However once spilled in the environment, it forms a hydrophobic layer which adversely affects soil properties by limiting availability of water and nutrients for crop productivity.

\section{SIGNIFICANCE STATEMENT}

This study discovered the environmental consequences of crude oil pollution to the Nigeria economy as the spill tend to degrade agricultural farming systems, microbial population and general health of the populace. The various component derived from the crude oil can be used in diversification by implementing policies that will be beneficial for the sustainable development, farming and adequate monitoring of crude oil drilling, processing and transportation in the Niger Delta region. This study will help the researchers, policy makers and farmers in bridging the antagonistic relations created by lack of communication and uncover the critical areas of interest for a sustainable economy for all. Thus a new theory on the evaluation of environmental impact assessment with experts, government agency, farmers and regions affected can be arrived.

\section{ACKNOWLEDGMENT}

This research was supported by funds from Late Dr. (Mrs.) O.K. Ohanmu and Nigerian Petroleum Development Corporation (NPDC), Benin city, Edo state.

\section{REFERENCES}

1. Ohanmu, E., S. Bako and M. Adelanwa, 2017. Effect of Oil Spillage on the Productivity of Pepper (Capsicum spp.). Lambert Academic Publishing, Germany.
2. Abii, T.A. and P.C. Nwosu, 2009. The effect of oil-spillage on the soil of eleme in Rivers State of the Niger-Delta area of Nigeria. Res. J. Environ. Sci., 3: 316-320.

3. Ohanmu, E.O., S.P. Bako and M.A. Adelanwa, 2014. Seasonal variation of Capsicum frutescens L. (Chilli pepper) to crude oil spill on soils from Ologbo, Edo State. Ann. Exp. Biol., 2:31-35.

4. Ojimba, T.P., 2011. Socio-economic variables associated with poverty in crude oil polluted crop farms in Rivers state, Nigeria. J. Applied Sci., 11: 462-472.

5. Patrick-Iwuanyanwu, K.C., C.C. Onyemaenu, M.O. Wegwu and E.O. Ayalogu, 2010. Haematotoxic effects of diets contaminated with petroleum products (kerosene and petrol) in wistar albino rats. Res. J. Environ. Toxicol., 4: 134-140.

6. NDDC., 2006. Niger Delta regional development master plan. Niger Delta Development Commission (NDDC), Port Harcourt, Nigeria, pp: 1-260.

7. Ekanem, S.A., B.J. Ejue, P.B. Amimi and R.A. Adalikwu, 2010. Living with oil: Towards an ethics of the environment in the Niger Delta. Afr. Res. Rev., 4: 17-30.

8. Ugbomeh, B.A. and A.O. Atubi, 2010. The role of the oil industry and the Nigerian state in defining the future of the Niger delta region of Nigeria. Afr. Res. Rev., 4: 103-112.

9. Eneh, O.C., 2011. A review on petroleum: Source, uses, processing, products and the environment. J. Applied Sci., 11: 2084-2091.

10. Mmon, P.C. and T. Deekor, 2010. Assessing the effectiveness of land farming in the remediation of hydrocarbon polluted soils in the Niger Delta, Nigeria. Res. J. Applied Sci. Engine. Technol., 2: 654-660.

11. Awake, 2003. Oil, will it ever run dry? Watch Tower Publications, November 8, 2003, pp: 3-12.

12. World Resource Institute, 1991. World Resources 1990-1991: A Guide to the Global Environment. Oxford University Press, New York.

13. Odu, C.T.I., 1981. Degradation and weathering of crude oil under tropical conditions. Proceedings of the International Seminar on the Petroleum Industry and the Nigerian Environment, November 9-12, 1981, Port Harcourt, Nigeria, pp: 143-153.

14. Clark, Jr.R.C. and D.W. Brown, 1977. Petroleum: Properties and Analyses in Biotic and Abiotic Systems. In: Effects of Petroleum on Arctic and Subarctic Marine Environments and Organisms, Malins, D.C. (Ed.)., Academic Press, New York, pp: $1-54$.

15. NEST., 1991. Nigeria's Threatened Environment: A National Profile. Nigerian Environmental Study/Action Teams, Ibadan, Nigeria, ISBN-13: 9789783120303, Pages: 288.

16. Adegeye, A.O., L.A. Ayodele and L.A. Ufito, 1993. Effect of oil exploration on the forest and wildlife resources in Delta state of Nigeria. Proceedings of Foresters Association of Nigeria, (FAN'93), Ikeja, Lagos, pp: 45-52. 
17. Bako, S.P., D. Chukwunonso and A.K. Adamu, 2008. Bio-remediation of refinery effluents by strains of Pseudomonas aerugenosa and Penicillium janthinellum. Applied Ecol. Environ. Res., 6: 49-60.

18. NDDC., 2010. Oil Spill Clean Up. Niger Delta Development Commission, Port Harcourt, Nigeria, pp: 23.

19. Udo, E.J. and A.A.A. Fayemi, 1975. The effect of oil pollution of soil on germination, growth and nutrient uptake of corn. J. Environ. Qual., 4: 537-540.

20. Stahl, P.D. and S.E. Williams, 1986. Oil shale process water affects activity of vesicular-arbuscular fungi and Rhizobium 4 years after application to soil. Soil Biol. Biochem., 18: 451-455.

21. Odebunmi, E.O., E.A. Ogunsakin and P.E.P. Ilukhor, 2002. Characterization of crude oils and petroleum products: (I) Elution liquid chromatographic separation and gas chromatographic analysis of crude oils and petroleum products. Bull. Chem. Soc. Ethiop., 16: 115-132.

22. FEPA., 1991. Environmental guidelines and standards for the petroleum industries in Nigeria (EGASPIN). Issued by Department of Petroleum Resources, Lagos

23. Pepper, I.L., C.P. Gerba and M.L. Brusseau, 1996. Pollution Science. Academic Press, New York.

24. Agbogidi, O.M., 2003. Response of Azolla africana Desv. and Salvinia nymphellula Desv. to the water soluble fraction of Odidi well crude oil. J. Sci. Technol. Res., 2: 76-80.

25. Nwilo, P.C., 1998. An overview of the implications of oil exploration on the environment. Infotechnology. Today, Maiden Edition, pp: 12-14.

26. Uzoije, A.P. and J.C. Agunwamba, 2011. Physiochemical properties of soil in relation to varying rates of crude oil pollution. J. Environ. Sci. Technol., 4: 313-323.

27. Nwankwo, D.I., 1986. Phytoplankton of a sewage disposal site in Lagos Lagoon, Nigeria I. algae. J. Biol. Sci., 1: 89-96.

28. Al-Qahtani, M.R.A., 2011. Effect of oil refinery sludge on plant growth and soil properties. Res. J. Environ. Sci., 5: 187-193.

29. Tanee, F.B.G. and L.A. Akonye, 2009. Effectiveness of Vigna unguiculata as a phytoremediation plant in the remediation of crude oil polluted soil for cassava (Manihot esculenta,Crantz) cultivation. J. Applied Sci. Environ. Manage., 13: 43-47.

30. Agbogidi, O.M. and E. Ayelo, 2010. Germination of African oil bean (Pentaclethra macrophylla, Benth.) seeds grown in crude oil polluted soil. Proceedings of the 2nd Biennial National Conference of the Forests and Forest Products Society, April 26-29, 2010, Federal University of Technology, Akure, Nigeria, pp: 105-111.

31. Bako, S.P., S.J. Oniye and L.S.P. Bako, 2011. Threat and potentials of invasive macrophtye species to inland freshwaters in relation to changing climate in Northern Nigeria. Proceedings of the 54th Symposium of the International Association for Vegetation Science, June 20-24, 2011, Lyon, France, pp: 20-22.
32. Idodo-Umeh, G. and A.E. Ogbeibu, 2010. Bioaccumulation of the heavy metals in cassava tubers and plantain fruits grown in soils impacted with petroleum and non-petroleum activities. Res. J. Environ. Sci., 4: 33-41.

33. Ekpo, M.A. and C.J. Ebeagwu, 2009. The effect of crude oil on microorganisms and dry matter of fluted pumpkin (Telfairia occidentalis). Scient. Res. Essay, 4: 733-739.

34. Khamehchiyan, M., A.H. Charkhabi and M. Tajik, 2007. Effects of crude oil contamination on geotechnical properties of clayey and sandy soils. Eng. Geol., 89: 220-229.

35. Agbogidi, O.M. and C.O. Egbuchua, 2010. Heavy metal concentrations in soil contaminated with spent engine oil in Asaba, Delta state, Nigeria. Acta Agron. Niger., 10: 65-69.

36. Russel, E.W., 1960. Soil Conditions and Plant Growth. John Wiley and Sons Ltd., New York.

37. Anoliefo, G.O. and D.F. Nwoko, 1995. Effects of spent lubricating oil on the growth of Capsicum annum L. and Lycopersicon esculentumMiller. Environ. Pollut., 88:361-364.

38. Smit, B., M. Stachowisk and E. Volkenburgh, 1989. Cellular processes limiting leaf growth in plants under hypoxic root stress. J. Exp. Bot., 40: 89-94.

39. Mary, A.O. and D.E. Dolor, 2007. An assessment of the growth of irvingia gabonensis (Aubry-lecomte Ex O'Rorte) bail seedlings as influenced by crude oil contamination of soil. Asian J. Plant Sci., 6: 1287-1292.

40. Bamidele, J.F., O.M. Agbogidi and O.M. Ohienbor, 2007. Phytotoxic effects of gasoline on Ischaemum rugosum (Salisb), a wetland species. Am. J. Plant Physiol., 2: 276-281.

41. Agbogidi, O.M., 2009. Yield components of six cultivars of cowpea (Vigna unguiculata L.) Walp grown on soil contaminated with spent engine oil. Acta Agron. Niger., 9: 1-6.

42. Chinda, A.C. and S.A. Braide, 2000. The impact of oil spills on the ecology and economy of Niger Delta. Proceedings of the Workshop on Sustainable Remediation Development Technology, (SRDT'00), Institute of Pollution Studies, Rivers State University of Science and Technology, Port Harcourt, pp: 1-11.

43. Holdgate, M.W., 1979. Targets of pollutants in the atmosphere. Philos. Trans. R. Soc. Lond. Series A: Math. Phys. Sci., 290: 591-607.

44. Omosun, G., A.A. Markson and O. Mbanasor, 2008. Growth and anatomy of Amaranthus hybridus as affected by different crude oil concentrations. Am.-Eurasian J. Scient. Res., 32: 70-74.

45. Amakiri, J.O. and F.A. Onofeghara, 1983. Effect of crude oil pollution on the growth of Zea mays, Abelmoschus esculentus and Capsicum frutescens. Oil Petrochem. Pollut., 1: 199-205.

46. Ohanmu, E.O., S.P. Bako and M.A. Adelanwa, 2014. Effect of crude oil polluted soil on the growth and survival of pepper (Capsicum annuum L.). Ann. Exp. Biol., 2: 5-10. 
47. Ebenezer, A., E.C. Amadi and P. Agi, 2010. Studies of the microflora, antigenemia and clinical signs of Bancroftian filariasisin Epic Greek Communities, Niger Delta, Nigeria. Int. Res. J. Micro., 2: 370 -374.

48. Achuba, F.I., 2006. The effect of sublethal concentrations of crude oil on the growth and metabolism of cowpea (Vigna unguiculata) seedlings. Environmentalist, 26: 17-20.

49. Eriyamremu, G.E., S.O. Asagba, E.C. Onyeneke and B. Aguebor-Ogie, 2007. Bonny light crude oil and its fractions alter radicle galactose dehydrogenase activity of beans (Phaseolus vulgaris L.) and Maize (Zea mays). Trends Applied Sci. Res., 2: 433-438.

50. Ekpo, M.A. and I.L. Nwaankpa, 2005. Effect of crude oil on microorganisms and growth of ginger (Zingiber officinale) in the tropics. J. Sustainable Trop. Agric. Res., 16: 67-71.

51. Asoquo, F.E., I.J. Ibanga and N. Idungafa, 2002. Effects of Qua Iboe (Nigerian) crude oil on the germination and growth of okra (Abelmoschus esculentus L.) and Fluted pumpkin (Telfaria occidentalis L.) in the tropics. J. Environ. Poll. Health, 1: 31-40.

52. Njoku, K.L., M.O. Akinola and B.O. Oboh, 2008. Germination, survival and growth of accessions of Glycine max L. (Merril) (Soybean) and Lycopersicon esculentum L. (Tomato) in crude oil polluted soil. Res. J. Environ. Toxicol., 2: 77-84.

53. Merckl, N., R. Schutze-Kraft and M. Arias, 2005. Influence of Fertilizer Level on Phytoremediation of Crude Oil-Contaminated Soils with the Tropical Grass Brachiaria brizantha (Hochst. ex A. Rich.) Stapf. In: Phytoremediation of Petroleum-Contaminated Soil, Merkl, N. (Ed.)., Margraf Publisher, Weikershim, pp: 71-83.
54. Wiltse, C.C., W.L. Rooney, Z. Chen, A.P. Schwab and M.K. Banks, 1998. Greenhouse evaluation of agronomic and crude oil-phytoremediation potential among alfalfa genotypes. J. Environ. Qual., 27: 169-173.

55. Agbogidi, O.M., P.G. Eruotor and S.O. Akparobi, 2007. Effects of time of application of crude oil to soil on the growth of maize (Zea mays L.). Res. J. Environ. Toxicol., 1: 116-123.

56. Anoliefo, G., O. Isikhuemhen and E. Ohimain, 2006. Sensitivity studies of the common bean (Vigna unguiculata) and Maize (Zea mays) to different soil types from the crude oil drilling site at Kutchalli, Nigeria (7 pp). J. Soils Sediments, 6: 30-36.

57. Vwioko, D.E., G.O. Anoliefo and S.D. Fashemi, 2006. Metal concentration in plant tissues of Ricinus communis L. (Castor oil) grown in soil contaminated with spent lubricating soil. J. Applied Environ. Manage., 10: 127-134.

58. Dung, E.J., L.S. Bombom and T.D. Agusomu, 2008. The effects of gas flaring on crops in the Niger Delta, Nigeria. GeoJournal, 73: 297-305.

59. Madejon, P., J.M. Murillo, T. Maranon, F. Cabrera and M.A.Soriano, 2003. Trace element and nutrient accumulation in sunflower plants two years after the Aznalcollar minespill. Sci. Total Environ., 307: 239-257.

60. Arnon, D.I., 1938. Microelements in culture solution experiments with higher plants. Am. J. Bot., 25: 322-325.

61. Epstein, E., 1972. Mineral Nutrition of Plants: Principles and Perspectives. John Willey and Sons, New York, pp: 210.

62. Khan, D.H. and B. Frankland, 1983. Effects of cadmium and lead on radish plants with particular reference to movement of metals through soil profile and plant. Plant Soil., 70: 335-345. 